TO:

Office of Scientific Computing, Office of Energy Research, Department of Energy

FROM: Paul G. Huray, Carolina Distinguished Professor $\quad$ f. $\mathbb{d} / \mathbb{A}$.

RE: Final Report on Award for "Partnership in Computational Science" (USC \# 22000F300) (DOE Grant \#DE-AC05-84OR21400)

DATE: $\quad$ Febmary 24, 1999

$$
\text { and covers } D E-F 605-93 E R 25759
$$

This js the final report for the "Partnership in Computational Science" (PICS) award DE-

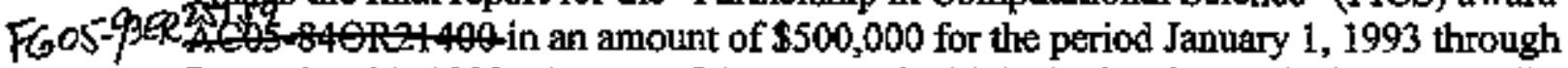

December 31, 1993. A copy of the proposal with its budget is attached as Appendix A. This report first describes the consequent significance of the DOE award in building infrastructure of high performance computing in the Southeast and then describes the work accomplished under this grant and a list of publications resulting from it.

\title{
Fistory of Subsequent Awards:
}

In late 1993, USC used the Intel Paragon Model A4 Parallel Supercomputer as the basis for a statewide supercomputer network. The three South Carolina research universities, Clemson, the Medical University of South Carolina, and the University of South Carolina signed a Memorandum of Understanding to use the parallel computer as the cornerstone facility for the netwotk. The Agreement was also signed by then Governor Carroll Campbell and Fred Sheheen, Executive Director of the state's Commission on Higher Education. A copy of that agreement is attached in Appendix B.

In 1994, South Carolina used the above cooperative agreement to request funding for the Experimental Systemic Initiative award for a South Carolina High Performance Computing Network. NSF invested \$450,874 in the program and the state Experimental Program to Stimulate Competitive Research (EPSCoR) matching allocation provided $\$ 487,347$ for the period Aug. 1, 1994 to July 31, 1996 to bring about systemic change in research computing in the state. The impact was enormous:

- The Paragon supercomputer network was upgraded to provide high-speed, highresolution access via seven Silicon graphics Indy workstations (at least one on every campus). An additional Indy 2 front end was added to the Paragon to allow highspeed disk transfer and to provide a multi-user interface.

- More than 100 faculty and students received tutorials from Patrick Fay, Beverly Huntsberger, and Abhijit Sengupta. These tutorials included hands-on experience using the Paragon via the state network.

- Thirteen graduate stidents were selected as South Carolina Supercomputer Network Graduate Fellows and taught other students how to use parallel computers.

- Three junior faculty from the College of Charleston, South Carolina State University and USC-Aiken were supported to become senior users of parallel computing. 
The Paragon computer led to a succession of programmatic developments that enhanced the research capability, not only in South Carolina, but also among southeastern universities:

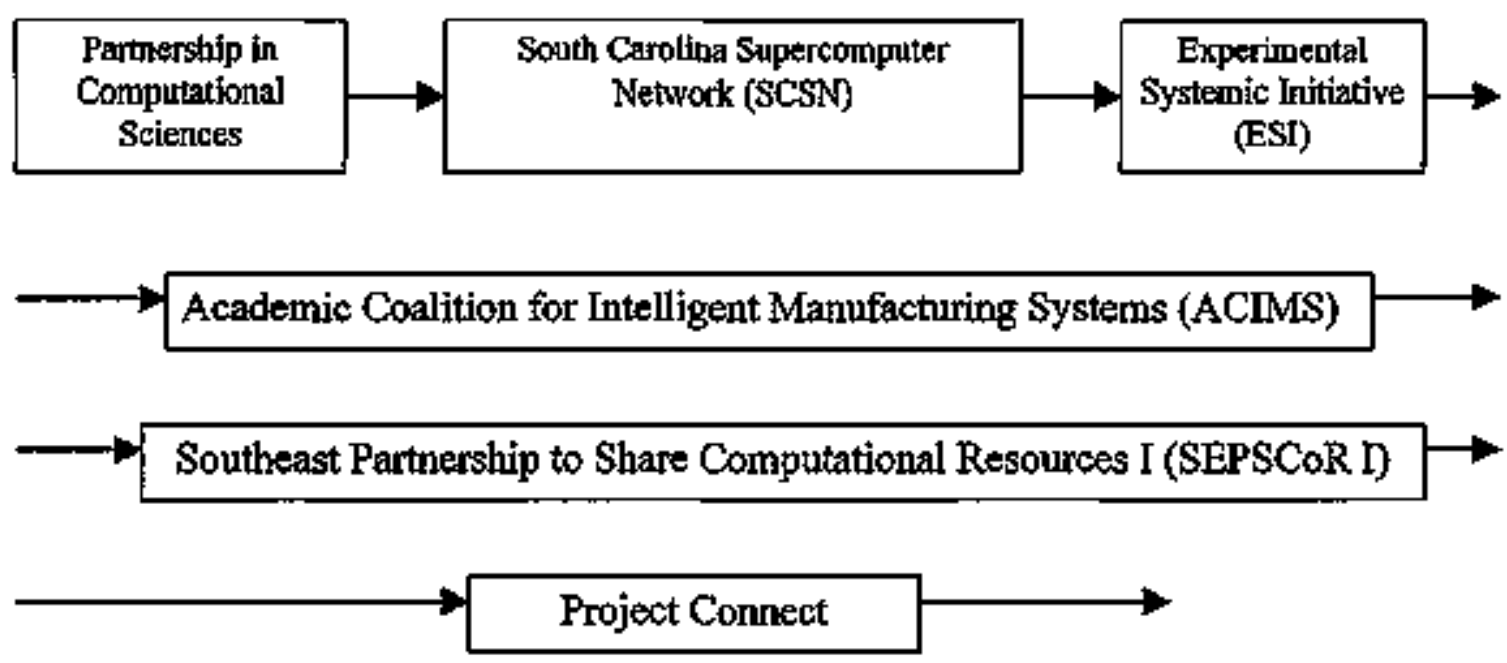

These projects were supported by the state of South Carolina, ARPA, NIST, the Department of Education, and NSF supported four of the awards. The total support for these infrastructure awards totaled more than $\$ 6.5$ million.

\section{PICS Results:}

The Groundwater Component of PICS was a consortium of five universities, Princeton, University of Texas at Austin, State University of New York, Stony Brook, Texas A \& $M$, and the University of South Carolina; and three national laboratories, Oak ridge National Laboratory, Brookhaven National Laboratory, and Savannah River Laboratory.

The Grand Challenge in Groundwater Remediation addressed the computational power issues of modeling efforts by focusing on massively parallel computing. The project sought to develop a new, state-of-the-art, parallelized flow and transport code to mode! groundwater transport as well as supporting technologies for parameter estimation (see http: $/$ www isc.tamu.edu/PICS/.) These issues are further explained at http $/ /$ hpcodmz.hpec.gov/pubs/blue $94 /$ section.5.6html, which cites the need for hierarchical models of groundwater flow and associated chemical transport at the local basin, and regional scales to assess waste transport and remediation schemes. Current models are limited computationally in two ways: first, models can only include a limited number of physical and chemical processes before computing runtimes become prohibitive; second, modules lack adequate field data to characterize geologic and chemical factors that influence contaminant behavior. High performance computing systems were needed both to model complex transport processes and to overcome data limitations by using computationally intensive parameter estimation techniques. The Partnership in Computational Science (PICS) explored new approaches to modeling groundwater flow at waste sites in extremely complex hydrogeologic settings. 
USC component activities included (See http $/ /$ www.math.sc.edu-sharplev/pics.htm)

1. Analysis and Code Development.

- Numerical solution of degenerate equations.

- Eulerian-Lagrangian method for convection-diffusion equations.

- Multiresolution analysis.

- Postprocessed simulations.

2. Graphical User Interfaces and Enabling Technologies.

- G3D - time animated 3D postprocessing tools

- G3D's Grid generation and model preprocessing http://wwwmath.sc,edu/ sharplev/PICS/USC PICS 4b.html

- Interactive tracking and steering for remote simulations

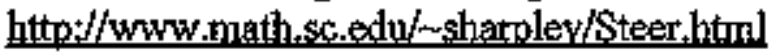

- Compression of 3D (and higher) data

3. Modeling and Field Studies.

4. Computational resources. hetp:/wwww.math.sc.edu/rsharpley/PICS/USC PICS 4a.html\#movie

5. Multiresolution analysis using biorthogonal wavelets and encoding algorithms were used to investigate data compression and archival of large geophysical data sets that arise in connection with simulations. In collaboration with Ronald DeVore and an ONR project, USC developed wavelet compression techniques for multidimensional data sets which achieve high compression for use in Remote Tracking and Steering of simulations on remote supercomputers. Our initjal work involved developing a 3D generalization of Shapiro's EZM encoder using 6-10 biorthogonal hyperbolic wavelets with appropriate extensions to handle logically rectangular data of arbitrary dimensions in the coordinate directions. In order to obtain higher compression rates and to make the transition from image compression to 3D (and higher dimensions) with arbitrary array sizes more transparent and efficient, we have developed new encoders which outperform current compression encoders even when restricted to the case of images.

Other potential uses of these multi-resolution methods are in the direction of 3D-feature extraction for registration in geophysical databases, denoising and assimilation of field data, and scaleup of parameter estimates from laboratory experiments. Wavelets are also being used to study noplinear conservation laws and parabolic/elliptic Partial Differential Equations.

The University of South Carolina contributed primarily in five areas to the PICS project: (i) ELLAM algorithm development for advection-diffusion-reaction equations, (ii) development and testing of data compression algorithms to enable interactive simulations over standard bandwidth networks, (iii) development of graphical user interfaces for preprocessing input data, model development, and post-processing simulations for analysis, (iv) development of a general purpose library for remote interactive tracking and steering of simulations on massively parallel machines, and (v) collaboration with the Savannah River Site in providing realistic field site data as test cases for the PICS 
simulators. More details on the University of South Carolina's PICS contributions and activities are available at http//www.math.sc.edu/-sharpley/pics.html.

The sensitive numerics of advection-diffusion equations, appearing both in the saturation equation of the flow code and in the transport equations, require careful treatment in order to efficiently achieve the accuracy required for these coupled model equations. South Carolina continued its collaboration with Princeton and Texas A\&M on EulerianLagrangian Localized Adjoint Methods (ELLAM) for the numerical solution of advection-dominated partial differential equations. Significant results have been obtained on the convergence analysis of ELLAM schemes (see Wang,H.1, Wang.H.2), development of algorithms for advection-diffusion-reaction equations (see Qin, Wang.H.1, Wang.H.2, Wang.H.3, Wang.H.4), domain decomposition and space-time local refinements (see Wang.H.2, Wang.H.4), and the numerical simulation of compositional models (see Qin).

Many numerical methods for the solution of one- and two-dimensional advectiondiffusion-reaction partial differential equations, including ELLAM schemes, Galerkin finite element methods, quadratic Petrov-Galerkin methods, cubic Petrov-Galerkin methods, streamline diffision methods, Flux Corrected Transport, and Godunov schemes, have been systematically compared under a variety of initial and boundary conditions. The result of these comparisons have demonstrated the strong potential of ELLAM schemes to address the model transport equations.

South Carolina, in collaboration with Princeton, Savannah River, and Texas A\&M provided boundary condition specifications. The primary input modules were developed by Mohamed Al-Lawatia and have been delivered to satisfy the corresponding part of the milestones. Complete documentation and examples were included. The modules were merged into the official GCT 1.3 code and conform to the new input standards. This effort was coordinated with Pasciak (BNL), Vassilev (TAMU), Celia (Princeton), and the G3D development team. Thorough testing has been completed for each of the primary WEB modules (grid, initial conditions, boundary conditions, and material properties). Special data structures were designed and implemented for the efficient building, handling and storage of time-dependent boundary condition data sets.

A comprehensive suite of graphical pre- and post-processors has been developed to assist practitioners with model formulation and development. These GUI's allow for tasy input of all necessary parameters and system properties, and for meaningfil graphical display of output from the numerical simulations. The current version of these interfaces has been developed through funding from $D O E$ with matching funds from the University of South Carolina. G3D currently provides a fully functional pre- and post-processing graphical interface that allows the user to easily genetate and modify the numerical grid, to input and modify soil and rock properties, and to impose appropriate initial and boundary conditions. It provides a data synthesis capability, which facilitates detection of user-input errors as well as providing an efficient methodology for refinement of the modeling process. G3D provides animated graphical display of evolving contaminant 
plumes in three-dimensions, with options to plot iso-concentration surfaces or color shadings with varying degrees of opacity.

Additional G3D tools include 3-D mouse view control, multiple views, VCR record and playback, overlay and stereo imaging, grid and model editing, including full boundary condition GUI editing for time-dependent boundary conditions of all types. Multiple scalar and vector data are simultaneously processed, as well as the simultaneous rendering of soil and fluid features. Additional images, model animations, and source codes are available from the WEB site printed above, and the URL $\mathrm{http} / /$ www.math.sc.edu/ sharpley/PICS/USC/PICS_4a_html/movie.

In order to provide for efficient and effective use of both the GUI's and the parallel simulators on remote massively parallel machines, we have also developed a general purpose Controller Library that is described in more detail in the next subsection.

An Interactive Tracking/Steering Library with the parallel machine (e.g., Paragon) as server and UNIX workstations (e.g. Silicon Graphics) as clients has been developed and may be obtained from the ORNL repository or from South Carolina's ftp site.

This is a general-purpose library which was developed for interactive remote tracking and steering of simulations and which conforms to specifications as set by GCT code developer J. Pasciak (BNL). The library has been tested on the satellite PICS Paragons, as well as the main production machines at ORNL, to ensure compatibility of the remote procedure cails with security at each site. Components delivered include: (i) client and server libraries, (ii) Steering/Tracking instrumented versions of GCT1.2 and US3D (ncite Johnson.1) for interactive remote use with the G3D graphical interface, (iii) four additional working example codes in increasing order of complexity, (iv) $\mathrm{TeX}$ user documentation, (v) FAQ (Frequently asked questions), 'Man' pages for on-line help. Additional information and a user manual are available online at the URL

The library permits remote tracking and steering of simulations on supercomputers from local workstations with user-determined levels of interruption to maintain load-balance, synchronization, and integrity of data to be transferred. This library has been ported to the MPI message passing language, has been coupled with G3D, specialized data compression modules, and three of the PICS groundwater contaminant codes (cite Johnson.1, Mahinthakumar) to provide interactive groundwater simulations on remote Paragons.

Extensive testing and usage of network connections to PICS machines at ORNL and member institutions, provided convincing evidence that the use of compatible data compression tools will be necessary for hydrologists and field engineers to perform interactive Grand Challenge simulations from their local workstations.

South Carolina has developed algorithms for both client and server compression modules to address this problenn and are tuning them for groundwater applications. During this grant perior, we have developed and implemented 3D algorithms (both single and 
multiple processor versions on the server machine, i.e. Paragon) designed to be coupled with the user interface codes and compress data as it is generated by GCT applications in a non-interruptive manner. The algorithms and research codes use nonlinear approximation and specialized entropy encoders, which have proven to be extremely successful for wavelet compression of $2 \mathrm{D}$ images applief to hyperbolic wavelet bases. We have developed 3D variants of Shapiro's method for comparison and have tested these implementations with our Steering library coupling with our G3D graphical user interface.

These compression algorithms applied to the both smooth (e.g., pressures) and to rough fields (transport solutions generated by the highly heterogeneous Old Burial Ground data at SRS) have achieved impressive rates of compression without discernable loss of visual information, and provides up to 1,200 times compression with excellent visual retention of qualitative features. Data was provided in several forms by our collaborators in the Environmental Sciences Division of the Savannah River Technology.

Project personnel James Brannan of Clemson University worked closely with Luther Hamm and Gregory Flach of SRS to assist in developing the theory, algorithms and software tools for processing raw data into input files for both HPC codes. The goal is to create software which incorporates scale-up techniques, data fusion methods, and permits input of soft or subjective geological knowledge. These issues will be critical for providing practicing hydrologists access to HPC simulators developed through the PICS project.

The SRS raw data was assimilated and used for flow and transport simulations on $\$ 128$ times 128 times 64 model runs, as well as several smaller model versions. Qualitative feedback of the model runs by SRS collaborators has resulted in a detailed flow field of the site.

The model data were also critical in debugging several components of the GCT codes and illustrated the need for distributed $\mathrm{I} / \mathrm{O}$ for model data in this application field. QuickTime and MPEG animations of the simulations were produced by applying G3D to the output of these models for both flow.

The original flow runs were performed on the XPS150 at ORNL by South Carolina personnel and the results were demonstrated at the ORNL booth during SuperComputing 95. 


\section{Bibliography of Publications Resulting from PICS}

R.J. Babarsky and R.C. Shappley, "Expanded Stability through Higher Temporal Accuracy for Time-centered Advection Schemes. "Monthly Weather Review. (June 1997), 1277-1295.

K. J. Bene, E. K. Paleologos, M. M. Meadows, "Geostatistical Analyses of Laboratory and In-situ Measurements of Satarated Hydraulic Conductivity", Abstracts of the 46th Annual Southeastern Section of the Geological Society of America (March 1997), p. 4.

K. J. Bene, R. P. Ray, M.M. Meadows, E. K. Paleologos, "Application of Geostatistics to Site Characterization", Annales Geophysicae, European Geophysical Society $(1997)$ p. C266.

Z. Gao, A. Andreev and R.C. Sharpley, "Elementary Encoding of Wavelet Coefficients", IMI Report 97:02, Department of Mathematics, University of South Carolina, Columbia, SC (Jan. 97).

L.S. Johnson, A. Kaulgud, R.C. Sharpley, R.E. Ewing, Z. Leyk, J. Pasciak, M. Celia, and J.R. Brannan, "Integration of Contaminant Transport Simulators on Parallel Machines with a Graphical User Interface for Remote Interactive Modeling", in Proceedings of the 1997 Simulation Multiconference, Atlanta, April 1997, Soc. for Computer Simulation International, San Diego.

L.S. Johnson, A. Kaulgud and R.C. Sharpley, G3D: "A 3D User Environment for Partial Differential Equations", IMA Report 97:01. Department of Mathematics, University of South Carolina, Columbia, SC (Jan. 97).

A. Kaulgud and R.C. Sharpley. "An Interactive Tracking/Steering Library", IMI Report 25:10, Department of Mathematics, University of South Carolina, Columbia, SC (Aug. 1995, rev. July 1997).

G. Mahinthakumar, R.C. Sharpley, A. Kaulgud, and L.S. Johnson, "Groundwater Remediation Experiments Using Interactive Computational Steering on the Intel Paragon", Intel.Supercomputer Users Group Annual Conference (ISUG97), Albuquerque, NM, June 11-13, 1997.

G. Qin, H. Wang, M.S. EspedaI, R.E, Ewing, and R.C. Sharpley, "Development of an ELLAM Simulator for Compositional Fluid Flows", submitted.

H. Wang, M. Al-Lawatia, and S.A. Telyakovskiy, "A Runge-Kutta Characteristic Method for First-order Linear Hyperbolic Equations", Numerical Methods for PDEs, (1997), 617-661 . 
H. Wang, M. Al-Lawatia, and R.C.Sharpley, "A Characteristic Domain Decomposition and Space-time Local Refinement Method for First-order Linear Hyperbolic Equations with Interfaces", submitted.

H. Wang, H.K. Dahle, R.E. Ewing, M.S. Espedal, R.C. Sharpley, and S. Man, "An Eulerian-Lagrangian Localized Adjoint Method for Advection-dispersion Equations in Two Dimensions and its Comparison to other Schemes", accepted for publication in SIAM J. Scientific Computing.

H. Wang and B-G Ersland, A characteristic domain decomposition technique for twophase flows with interfaces, accepted for publication in Proceedings of the Ninth International Conference on Domain Decomposition Methods, Ullensvang, Norway, June 1996.

Sample model runs of the spread of a contaminant which were generated by PICS codes on USC's Paragon: http $/ /$ www.math.sc.edu/ sharplev/PICS/USC.PICS 4a.html. 


\section{ATTACBMENT A \\ ATTACHBET A \\ THE UNIVERSITY OF SOUTH CAROLINA \\ Columana camrus}

Bal G. thuray, Vice frowuse Prolessor of Plystiss

Decenter 15. 1992
106 Cblutste: Phiikling

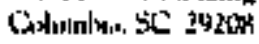
$807.75-41520$ FAX $624 ; \quad ; 57$

Dr. Gary Johnson, Program Manager

U.S. Departuent of Energy

Scientific Computing Staff, MS G-236/GTN

Washington, DC 20585

Dear Dr. Johnson:

On behall of the University of Soth Carolina (USC). I am hereby requesting a grant in the amount of $\$ 500,000$, which will be matched by USC $(\$ 300,000)$ and by an Intel infrastructure Grant $(\$ 739,000)$ and discount from the Intel Corporation $(\$ 171,000)$. These funds wilt be used for the purchase of an Intel Paragon XP/S Model A4 parallel computer, includint maintenance and operating software, with a total retait value of $\$ 1,710,000$.

The proposed DOE grant wil] additionally be matched as follows:

1) USC will provide facilities for the computer and for offices and support within an spectally designated research center,

2) The Intel Corporation wllt provide one-half FTE for an operating techsician, to be matched with sunds from an EPSCOR grant so as to provide a full-time technician;

3) Leading faculty from both the USC Colleges of Engineering and Science and Mathematics, as well as junior faculty, pust-doctoral fellows, and graduate students will consmit time and resources from various grants to the operation; and

4. The State of South Carolina is expectef to waive approximately $\$ 30,000$ in sales tax.

In tetum for this proposed grant, nominally one-half of the cycles on this machine will be dedicated entirely to the DOE funded Parthership in Computational Sciences (PICS) for the life of the program. These cycles will be utilized by USC researchers in collaboration with sesearctress at other PIC5 miversities and Federal Labs for developing code to be an on the larger 512-node Intel Paragon to be installed at Oak Ridge National Laboratory. The renainder of the cycles will be dedicated to other research programs including site-spectfic Hazardous $W$ uste and Environmental Restoration programs at the Savannah Rjver Site.

Sincerely, 

Sintar
Department of Energy

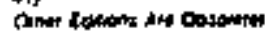
Ditlce of Energy Pesearch (OER)
Face Page.
12 aneye

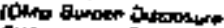

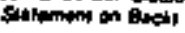

ITLE OF PROPOSED RESEARCH: _ Partnership In Computational Science

PEEASE TYPE THE FOLLOWING INFORMATION;

1 catalog of fegenal domestic assistance NUMBER: 91.049

2. CONGAESTIONAL DISTRIÇ,;

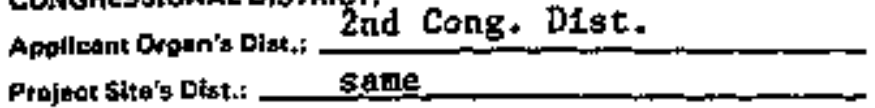

3 I.R.S. ENTITY IDENTIFICATION OA SOCIAL SECURITY NUMIBER. $57-6001153$

* AAEA OF RESEARCH OR ANNOUNCEMENT TITLE/NLIMEER SK966-19

5. HAS THIS RESEARCH PAOPOSAL GEEN SUBMITTEO TO ANY OTHEA FEDERAL AGENCYT $\square$ yas $C$ no PLEASE LIST

8. DORPOEH FAOCAALS STAFF EOWTACT (if known) Gary Johnson

7. TYPE OF APPLICATION: $\alpha$ Now E Concinuation C supplement C Renewal C Revision

:6. PRINCIPAL INVESTIGATORIPROGAAM DIRECTOR NAME, TITLE, ADORESS AND PHONE NUMBER

Paul G. Huray

Senzor V.P. for Research

Dniverstty of South Carolina

Columbia, S.C. 29208

Phone (803) $777-9520$

Fax (803) 777-9557

Internet: pghurayênivscvm.csd. scarolina , eck
8. ORGANizATION TYPE: Logal Government $C$ Stale Gavertment [ Non-Prolit F Hospital ? Indion Ttibal Gowernment [ Individusl Other "Instlturlon of ftigher Educarion E For.Protte $匚$ ISmall atainess 5 Disodvantaged Butiness $\square$ sial [ Womon-owned (C)

\section{Q. CUARENT DOE AWARO NUMBER (IF APPLICAELE)}

TO. WHL THAS RESEARCH INNOLVE:

10A. Human Subjects no 苗 1 yes, $\square$

Extmption Na.

IfG Approval Datu

Assurante of Compllange No.

108, Vertebrale Animals nolb If yes, D LACUCC Agproval Dale Antmal Wellare Asturance too.

11. AMOUNT GEOUESTED FAOM DOE FOR ENTTRE PAOJEOT PERIOD $\$ \$ 00,000$

12. DUAATION OF EMTIRE PROJECT PERIOD

$$
\frac{1 / 1 / 93}{\text { Mo/dsy/yr. }} \text { to } \frac{12 / 31 / 93}{\text { Mo/day/yr. }}
$$

13. REOUESTED AYYARD START DATE $1 / 1 / 93$

\{Wo/day/rr.\}

14. IS APPLICANT DELINOUENY ON ANY FEDURAL DEDT?

- Yes (If "Yes," attach an axplanghus) $\mathrm{C}$ No

16. ORGANIZATIOH'S NAME, ADDRESS AND CERTMFMG REPRESENTATIVE'S NAME, TTIF AND PHONE NUMEER

Sponsozed Frograms and Research University of South Caroline Columbia, sC 29208

Ardis Savory, Associate Fice Provost.

\section{SIGNATURE OF PAINCIPAL INVESTIGATOR/} PAOGRAM OTRECTOA Deit

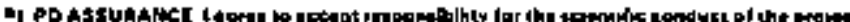

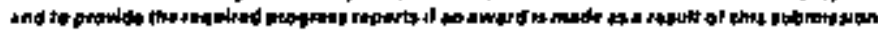

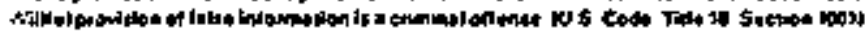

\section{SHGNATURE OF OAGANIZATION'S CERTIFYINE} REPRESTNTATIVE

\section{Date}

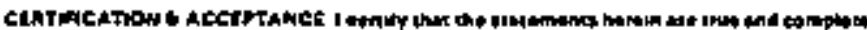

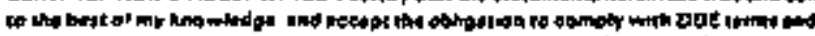

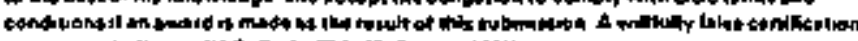

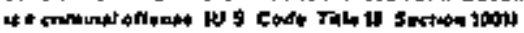

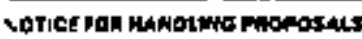

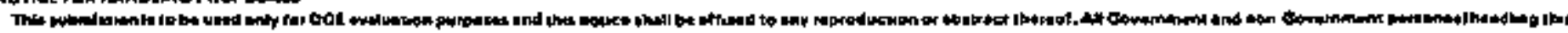

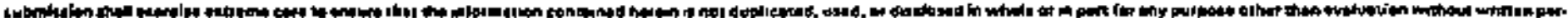

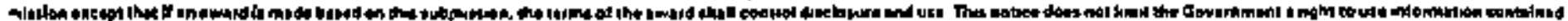

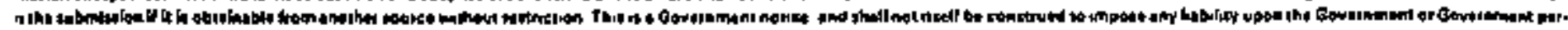

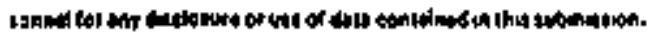

- munact act stratenkent

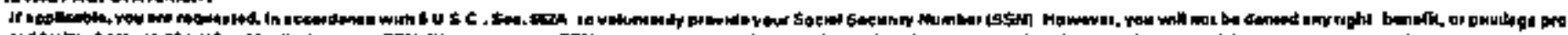

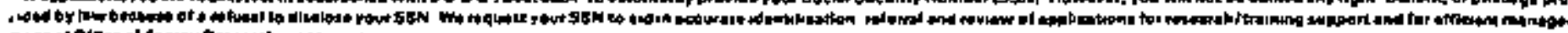

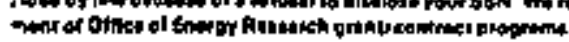


 \\ $1910-1400$

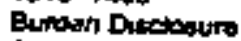 \\ Sinloment on Botk \\ U.S. DEPARTMENT Ö ENERGY NOTICE OF ENEAGY RDED PROJECT}

1. DOE CONTRACT OF GRANT NUMBER_ DE-AC05-840R21400
H. New contract
Continuation/Revision

2. A. NAME OF PEFIOORING ORGANIZATION

Universtty of South Carolina

B. Department or Division Office of Research

C. Stret Address 106 Osborne Admintatration Building
City Columbia
State
SC
29208

D. Type of Pertoming Organization (ctrcle only one two-letter code)

Cu-College, university, or trade school

NP-Foundation of laboratory not operated for proffi

EG-Electric or gas utility ST-Pegtanal, State. or local govemment tacility

FF-Federally ftuded RDED centers or laboratory operated for agency of US government

in-Private industry

TA-Trade or prolessional organization .

US-Federal Agency

XX-Other

3. PRINCIPAL OR SENIOR INVESTIGATOR
A. Last Huray
First Paul MI

B. Phone: Commercial

(803) 777-9520 FTS

4. DOE SPONSOFING OFFICE OR DIVISION

Scientific Conputing Staff

5. TILLE OF PROJECT

Parthership in Computational Science

6. DESCRIPTIVE SUMMABY (limit to 200 words)

See attached

7. RESPONDENT INFORMATON. List rame and address of person filling out this form. Give telephone number and extension where person can be reached. Record the date this form was completed or updated. This inlomation will not be published.

Last Huray First_Raul MH

Address University of South Garolina, office of Research, 106 Osborse

Cixy Columbia State Sc Zip 29208

Phone_(803) 777-9520

Date _ $12 / 15 / 92$ 


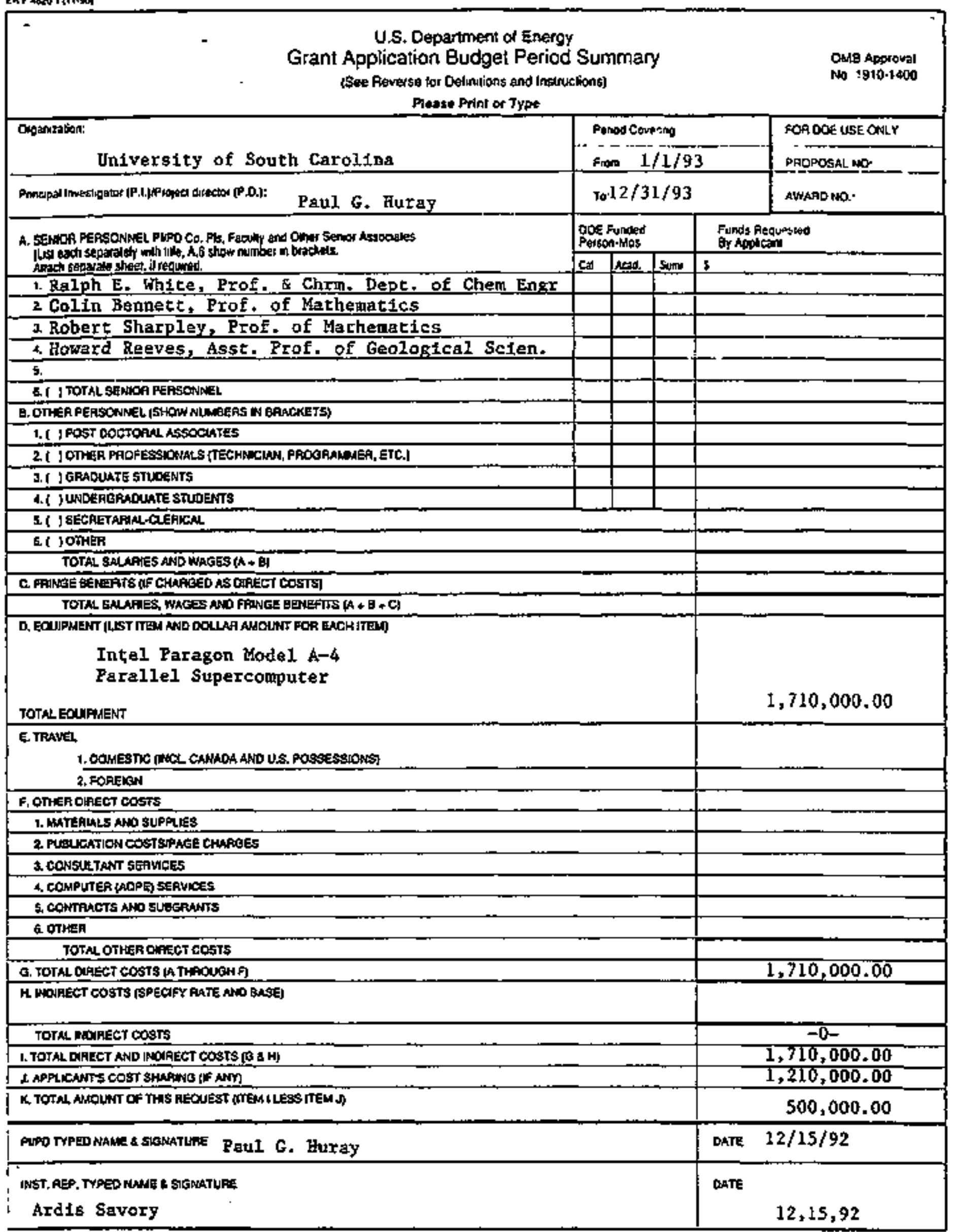




\section{BUDGET}

Purchase of the following equipment is proposed:

Configuration: Intel Paragon Parallel Supercomputer

4.2 G-flop peak performance

56 each i860-XP $16 \mathrm{~m}$-byte processing nodes

3 mass storage RAID arrays

1 multiuser service node

1 VME interface

1 Ethemet controller

I backup tape drive

Purchase Price:

Retail Price (see attached quote): $\quad \$ 1,710,000.00$

Funding Request:

Retail Price

Less: USC Match:

Less: Intel University Discount:

Intel Infrastructure Grant:
$\$ 1,710,000.00$

$(300,000.00)$

$(171,000.00)$

$(739,000.00)$

Total Requested:

$\$ 500.000 .00$

Included in the purchase price is three years of maintenance at an approximate value of $\$ 63,000$ per year, for a total of $\$ 189,000$. USC will continue to provide maintenance on the Intel machine after the end of this three-year period. USC will provide additional matching to this grant request in the form of facilities to house the computer and provide space for researchers and support activities, operational support.fiom other grants, and anticipated waiver of sales tax from the State of South Carolina. One-half of the cycles (nominally) will be devoted to use by USC researchers under the DOE sponsored PICS program

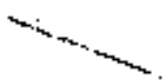


U.S. Depentment of Enowgy

GAANT APPLICATION

PROJECT PEAIOD SUMMARY

Cana artions

(hitust be compleied for at new and renawal applications,

$\mathbf{I}$

Please Prtal ot Typo

\begin{tabular}{|c|c|c|c|c|c|}
\hline Celegories & 01 Budgol Partod & O2 Budgel Perlod & 03 Budgat Perlat & D4 Budgal Paskad & OS Budget Perlad \\
\hline A. Sealor Persannel Totuts & & & & ' & \\
\hline \multicolumn{6}{|l|}{ G, Othepr Parsonanel Totats } \\
\hline C. Fringe Bentill Toluti & & & & & $\mathbf{I}$ \\
\hline \multicolumn{6}{|l|}{ Talal of A, $\mathrm{\theta}$ \& $\mathrm{C}$} \\
\hline D. Equlpment & $1,710,000.00$ & & & & \\
\hline \multicolumn{6}{|l|}{ E. Truvet $\quad$ 1. Dombsule } \\
\hline 2. Forelgn & & & & $\cdot$ & \\
\hline F. Diner Dicecl Cosit & & & & & 1 \\
\hline A. Tolal Ciract Cosis & $1,710,000.00$ & & & & - \\
\hline \multicolumn{6}{|l|}{ W. Totwh Indirect Cosis } \\
\hline I. Total DWeet \& Indirect Coslg & $1,710,000,00$ & & & & \\
\hline J. Appitgent's Gasl-Gharling (if Any) & $1,210,000,00$ & & & & \\
\hline $\begin{array}{l}\text { K. Tots Amount of Roquest } \\
\text { (liem l, Leas litem S.) }\end{array}$ & (i) $500,000.00$ & (2) & (3) & (4) & $|\xi|$ \\
\hline
\end{tabular}

- Thli ahoutd \&qual tiem K an Budgol Perlod Summary (EAF/AE20.1)

ESTIMATE

TOTAL COST OF PभOJECT
$\$ 500,000.00$
(add $K(1)$ thru (5))




\title{
Memorandum of Understanding
}

to establish a

\author{
South Carolina University High Performance Computing System
}

\section{South Carolina University Research Computing Background:}

In November of 1991. Govemor Carrol Campbell called for South Carolinta instinutions of Higher Educarion to study the needs and oppornunities for a shared state Figh Performance Computing System. In tesponse, an ad hoc panel consisting of representatives of the research universities and state computational offices was assembled under the auspices of the Comrission on Higher Educarion. The committee adopsed working principles and conducted a survey of exisang equipment and needs for the faculty of the three research universities. The comminee merged the universicy reports and produced a long list of joirt research needs which were unmet by existing computer resources. The survey revealed that incividual South Carolina researchers had procured a number of high performance workstations to accomplisth research projects funded by exrernal sources (mostly by agencies of the Federal Government) but that those computers were not generally available to all users. The committee concluded that some of the state research needs could be met through a pooling of compurer resources among the three research universities.

In parallel, the commitee addressed the potential source of funds to support the procurement of an additional computer system to be shared amont the state's tesearchers. A variecy of oprions were considered. but because of limizations of the sate budget a direct request for stare funding was noc pursued.

\section{The Universitr Agreement:}

In order to begin a process, whereby the scare's researchers sinare tieir computer resources, Clemson, USC and MUSC hereby agree to ininiate a shared, nerworked computer system. The system will be designed to allow evolution to the most desirable configuracion which sarisfies the most research needs at optimum cost Although the evolution may require the procurement of larger computers in funte years, the universities agree to begin the system within their available resources, and by urilizing statewide links to one another provided by the Internet

The universicies agree, where practicable, to procure hardware and system sofrware which will allow and encourage compatble growh and will utilize their individual compuress on a more cortanuous basis. The existing compurer operations staff at each of the institurions will maintain their respective portion of the system but will work in concert with one another via a joint 
advisory committe to formulate strategy and build a computing infrasructure which supports the maximum number of researchers.

Initiating a Joint Research Computing Srstem:

To produce a tangible product for researchers of the State of South Carolina in a timely fashion, the research universities have established a set of tasks which will allow the State to accomplish ins overall research objectives:

1. Establish a Joint Computational Advisory Committee: The three South Carolina research insututions will establish a joint compotational advisory committec with the objective of developing a common market for research computing through shared resources.

2. Establish Common Operating Systems for Workstations: USC, Clemson and MUSC will endeavor to establish clusters of workstations which serve the needs of their research faculty via compatible campus wide nerworks. The Joint Compunaionat Advisory Committe will assist the insciurions in defining and implementing a common operating system.

3. Jointly Provide High Performance Computer Access to Researchers: A statewide High Performance Computing System will be initiated through common access to an Intel Paragon Computer. The Joint Compurational Advisory Commimee will assist the institutions by assuring that the High Performance Conputing System is available from workstanions on the system which adopt the common operating systert.

4. Evolve the Joint HPC System: The Joint Computanonal Advisory Commitree will assist the research inscitutions in procuring future hardware and software which is compadble. The objective will be to encourage the evolution of individual campus compurers which are not duplicitous but which provide greater system-wide strength.
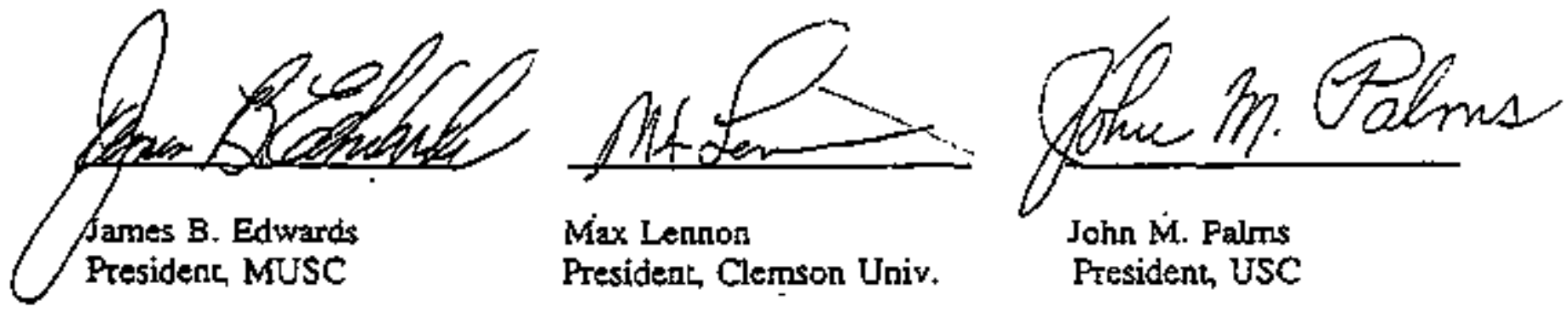


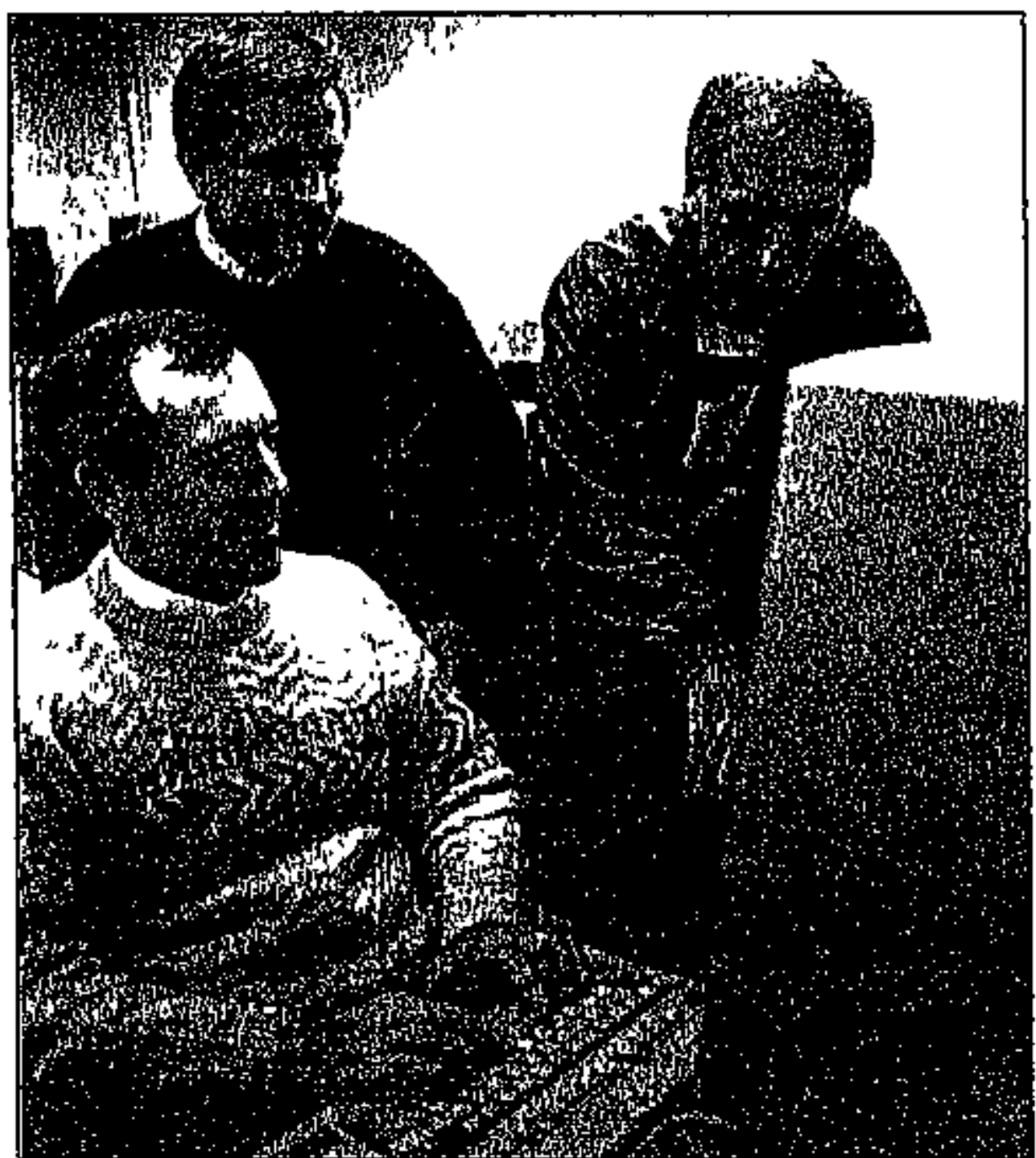

Fay (seated), loge on to Paragon wilh Dr. Rubert Sharpley (center) and Ir. Ron 1)eVore, lroth of the Departmetal of Malhetinglies.

\section{Scientist hired to teach faculty, students use of Paragon computer}

Dy Cluris Flom

With its flashing lights and sleck, black front panel, the University's new Intel Part: gon A-4 parallel computer tooks as powerful os it's billed to be, and thal's powerfut4 billion computations per second.

Unfortunalely, speed and power do not equate with ease of use. When it conves 10 computers, the phrase "user friendly" is a relalive 1 erm. "It's a Unix-based sysiem, whish is farniliar to esers of sctentific work stations." said Dr. Patrick Fay, a new compulational scientist in the Office of Research. "II's meanl for people with largescale contpuling problems and large capacity memory needs."

Fay plans to nake the experience of using lhe Paragoni computer a positive onte. In fact, thal's fus! whal lio was litred to do: work witls faculiy and graduate studeitt tosearcluers who want to use the Paragon.

"The computer is not that difficult in itself to use. The bardest part to to adapt one's research coties to run in parailel fomm," Fay saich. "J)knt"s not a trivial thing to to. bul there is really no ofler choice fthan partllel processing] tor some large-scale reseurch problems."

Fay is no stranger to comptlets, having worked with many different sysleıns during the past l4 years. And he's tho stranger to USC Columbia, either, having received a bachelot's degree in physics in 1980, and a MIBS degree (Spanish track) in IS87, Fay recently earned lis Ph.D. in physics from Clemson Unjuersily.

"At Clenson, we were using a very fast workslation 10 carry out simulations wilh 5,000 atoms. It would take the machine several weeks to complele the compula. lions," Fay said. "This Paragon machtne could do the same calcutations avemight."

A bright nole for researchers: USC has a site license for Parasofi Express, an integrated softwsro package tha! allows paralle! programs to be developed in atmost any type of workstation. Programs using Express can be developed, lested and run on workstations, then moved to the Paregon withoul changes when supercomputer perFormarce is needed. "It's best if researchers start using the software early on in a researcli project," Fay saitd.

He topes to offer seminars soon on use of the Paragon computer, and he encourages inlerested foculty members and grodu. ate students to calt him at 7-4804 or send a message to his E-mail address: pfay $Q$ ker mit.csu.scarolina.edu to arranee introductory and twontal sessions on the Paragon.

\section{Major gifts from}




\section{South Carolina Supercomputer Network \\ News Conference \\ Agenda}

10 a.m. - Computer Services butiding/second floor

Demonstration: Paul Huray will be present to welcome and explain the demonswation (Governor and the press will be key people present)

10:15 a.m. - third floor auditortum (Governor, press, Dr. Palms, Tim Walgren, representadives trom Clemson, MUSC and USC, as well as EPSCOR representatives)

\section{Formal Announcernent:}

Dr. Palms: Welcome

Announce acquisition and agreement Introduçe speakers:

Gov. Carroll Campbelt

Tim Walgren, vice president of Alumax in

Charleston and chairman of the Governor's Science and Marh Advisory Commirtee

Goy. Cartoll Campbell: Importance of the supercomputer and agreement to South Caroling

Tim Walgren:

Benefits to higher education ano industry of

10:35 a.m.

Or. Palms: concluoting remarts

having this high tech tool available in state

10:35-71 a.m.

Additional demonstratons on second floor 


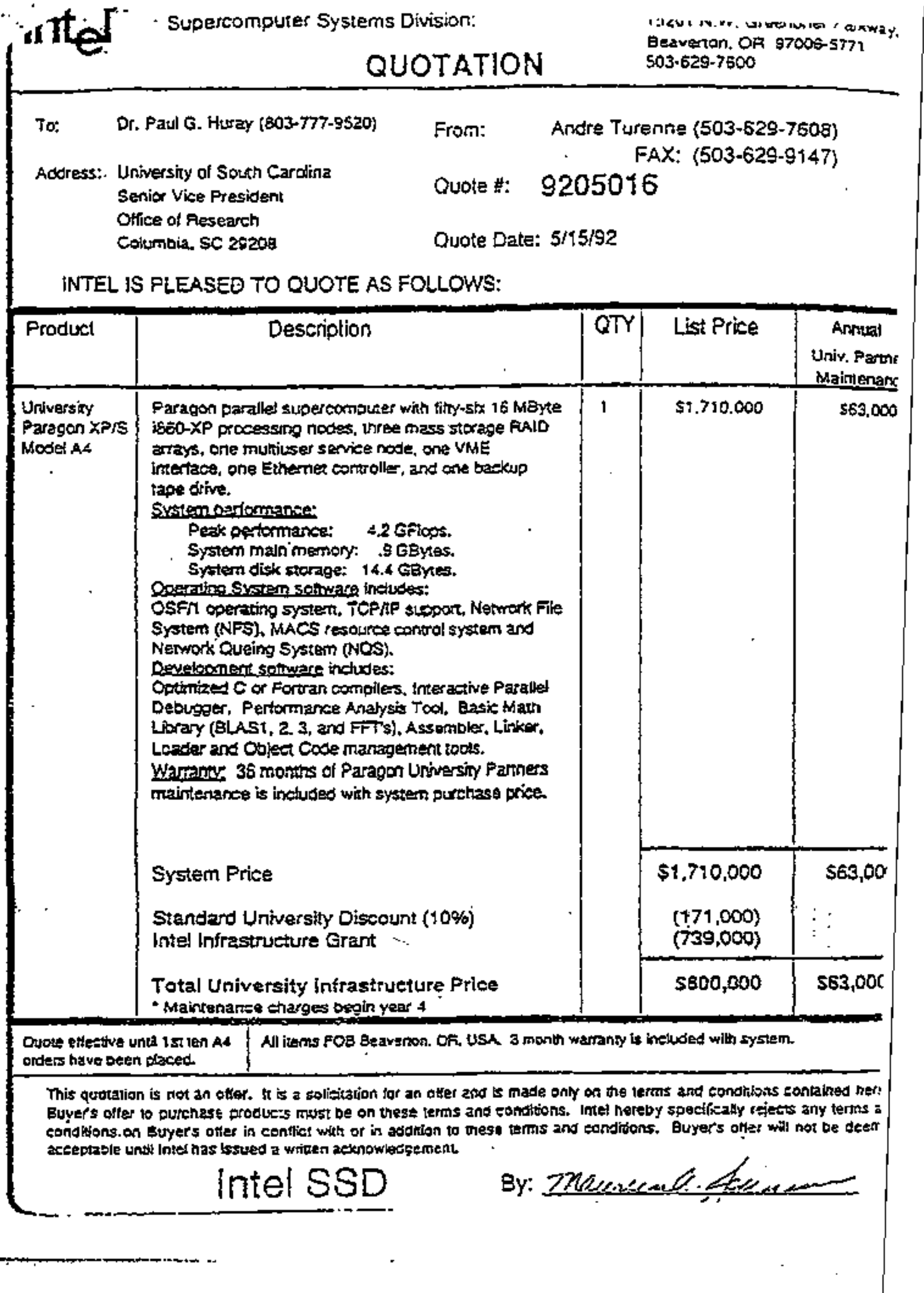


FOR MORE INFOAMATION, CONTACT:

Debra Alten or Jo Fleischer
For Immediate Release Novernber 18, 1993

Admno69

\section{South Caralina universities linked by Intel supercomputer}

The most powerful computer in the histary of South Carotina, which will be shared by the state's research universities, was unveiled by Gov, Carroll Campbell today (Nov. 18).

The $\$ 1.75$ million Intel sugercompurer, capable of $\mathbf{5}$ bition calculations per second, was demonsurated for Campbell and hipher education officials in the University of South Carolina's Computer Servicas building.

The machine was acquited through a resesrch association with the U.S. Department of Energy. but an agreement will make at least half of the machine's computing capacity available to researchers in all disciplines at Clamson University, the Medical University of South Caralina and USC.

This is the most powerful computer that has ever been used for any purpose in South Cardina, and it is very gratifying to see it used in a collaborative affor involving the state's research universities and the Deparment of Energy" Campbell said. "This cooperation will produce important benefits for students and researchers in South Carolina, and provide important research for business and industrial growth."

Using vacious computer networks, professors at the state's research universities will be abie to gati access to the computer from their own offices. Researchers say its enormous capacity will bo valuable In probing comptex problems such as global warraing and drug interactions.

- Joining in this computer network has brought South Carolina research universities a learnind tool that is available in just a handful of other states. And it was done at a cost of less than $\$ 300,000$ to the taxpayers," Campbell said. 
The supercomputer's principal use will be as part of the DOE's Partnership in Computationat Science (PICS) program, which provided a $\$ 500,000$ grant toward its purchase. USC provided approximately $\$ 300,000$, while the Intel Supercomputer Division provided a grant of $\$ 739,000$ plus software and a three-yeat maintenace contract to sid in the purchase of the intel Paragon A-4 supercomputer.

The PICS effort \$eeks to bring povemmental, industrial and academic researchers topether to develop faster and faster computers and the software to operate them as a means to stiving major problems such as groundwater contamination. The consortium includes the Oak Ridge National Laboratory in Fonnessee, Ames Laboratory in towa and Brookhaven Nztional Laboratory in New York, plus Fice University, the Univerșity of Tennessee, State University af New Yark at Stony Brook, Texas A\&M University and Vanderbilt University.

-This research has important implications for a number of tindustries, many of which are grappling with the challenge of monitoring and protecting the environment," said Tim Walgfen, chairman of the Governor's Science and Math Advisory Commizea. Ft shows how science research and industry needs ate often closely linked and how universities and business can both find benefits in research collaborations."

USC researchers are now involved in fundamental science research probing the spread of contaminants in groundwater at the DOE's Szvannah River and Oak Ridoe sites. "This computer will be involved in predicting exactly what is happening with the flow or diffusion of various contarninants under the ground," said Dr. Psul Huray of USC, the principal research investigator for the Energy Deparment grant that helped fund the supercomputer acquisition.

The development of mathematical models that can exploit new computer technology would save millions of doltars over current methods of determining the presence of poslutants, Huray said.

The Intel machine maximizes its capacity with paraltel processing, meaning that it divides a garticular problem into pieces that are calcutated simultaneously, then the components are cornpiled into an overall solution. 


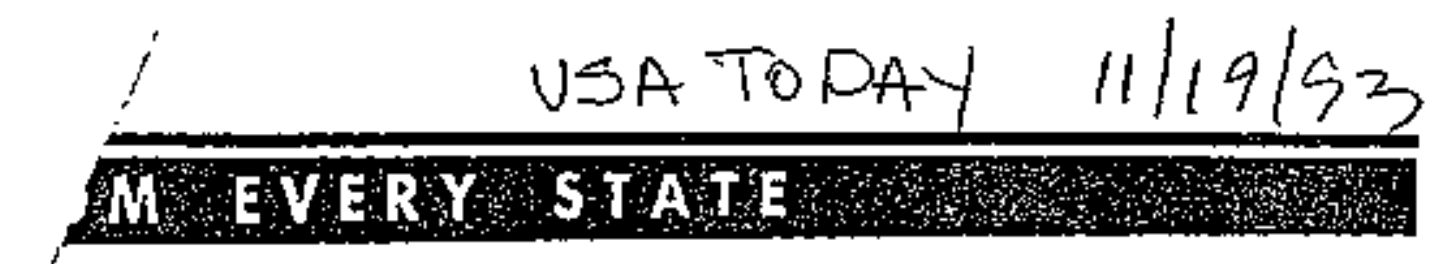

4 Nancy Keecian siid. Lawmakers ; meet in special seston Nov. 29.

\section{NEBAASKA}

LNACoux - The Dept of Soctal Services ts stodying a pian to let it sefre tax refunds and knttery winmoges ( Whoth over \$500) of peophe behind th chitd support.

\section{NEVADA}

SPAAKS - Whato Comty School Beard Chalroro hillches Wrigtid's residency stams woo't be challenped because be majnbilins entugh tesidency in his dorrict the dfuict artomey's oflece says A ditizen had complintex.

\section{NEW HAMPSHIRE}

X모도실 - A panel oo sexuala thatomitted dlseases has voled gprafnst recomtmenditg condom distributton in Keene Middte Sebool. It will, bowever, forward that proposel and about to others wo the sehool board tor diseneston.

\section{NEW JERSEY}

HOBOKEN - Mfoyor Anthom Rusto sald hets optimlade Franl Stracra's bortetown will be the sitte of a borary and rivecum in the croonar's boone. Other comtenders: Now York and Washtngton, D.C

\section{NEW MEXICO}

SANTA FE - The stote Enot toement Depe glans to tortal up w id $v e \pi$ wels to Ty to fod the sonirse of pollution in a mater well. High bevels of ethylene diturornide led to the closing of the Sarare de Cristo bater $\mathrm{Co}$, well last month

\section{NEW YOAK}

BNFFALO - Unive itg of Busfialo law sction stopin't let Pentagon recruilers to campus a stale Stoprene Coar: wotdon ruled The corrt backed of a festian stu dent who said $\mathrm{ml}$. ary remulkers trouldn't loteryte her gise to her semual ortentation .... NEW YORK - lases resum in the last Nep York ofy sthool losed stace Sep.

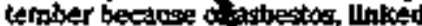
to cancer. The rub: ances stilt must be removed trobi areas in 300 school boilding.

\section{NORTH CAROLI:}

CHAPEL HAL - The UTH...' stry al Norch Carotine-Chapel Biti wou a 7250.000 grant trom the Car Lets for Divease Control and Pre veodion to develop a national criln: tni center for public bealth odictak Mission: nefp smokers quit; kesp people jorm starting abour government reform. United Wo Stend Anerica otjctals said. Veaver the Crvic Atuditoritum

\section{OHIO}

COLUMEUS - A gavermment board biocked the displys of a Curbtumas tree or menorah ar the Statebousse, but OKCd a permity tor the KKTK w taltiy there on Dr. Mart in Luther Kang Jr's birtboy.

\section{OKAHOMA}

GUTHRE - state methezl exsmbers roorked to identity the colned bodles of two geople kliter when a surall aimplane dipped a power line crastied tmo a barn and then elusht fre Wedreosday.

\section{OREGON}

PCfTLANd - The state 50 prepole Caurt bes dented white sor

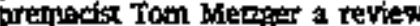
of the \$12.5 million verdic appinst him for encouraging stinheads to kill on Euriopian in '88. The denial clears the tray to seise Metroys esses far reschuton.

\section{PENNSYLVANIA}

HARAISPUAR - Electoos of ielats cetrfied Wutian Stiosan's 163-wore Senare viceny and Demo. cris inmedlately swore bim in betore the GOP colutd seek an aD peat Rivil Bruce Marts is chat.

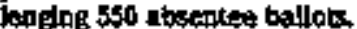

\section{RHODE ISLAND}

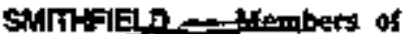

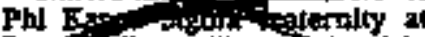
Ap w college wit] spend the nigh cordboard shanties to drat af tention on homelesspess and rafse abour $\$ 2,000$ for MfeAnley Honse, a Prowidente streiter.

\section{SOUTH CAROLNA}

COLUMAIA - A 51.75 milllan soper bilition calculadons per second wos unvelled at the Universicy of Sooth Caroliph itll be shared by researchers at USC Gelrson Jaiversity and the Medical Uoforerity of South Carollnt.

\section{SOUTH DAKOTA}

RAPID CITY - Northwet wil bo the onty major tiritue in coser atter United Aistines - elipie tack

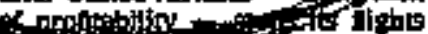

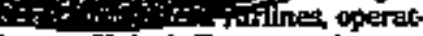
ing Uxiced Brpress phans to enes us is seryles

\section{TENNESSEE}

MEMPIt's - A repor is dete nert month od wbetber the clly

\section{TEXAS}

HOUSTON - Orficlats warned peorple not to eat lish or crabs from Clear Greek, which borders Harris Brazpria and Galveton countie Tett show the presence of two strpected cancervenusing chemikals.... SAN MARCOS The Alphe Kapres Aloha sorority at Southwex Texas State Universioy has beter gropended until "97 due to haring violadions, offelals sty.

\section{UTAH}

SALT LAKE CTY - A ÂvE-day wast for the purchtse of ung fon drew the support of majorty sal Lake Conncy coxtrnicsioners Jirs Bradiey and Randy Horiuchi.

\section{VERMONT}

DUXELURY - Bartroad Uidon Schoot Buard oted lerting some teachers and the school misse the pense condoms to bight school sar dents It's part of a program of dite eussing venersal dIseases. srustag abstimence. Perent masy excetitde thesir otin children.

\section{VIAGINIA}

VRGMTA BEACH - A NAVY F*14 Tomeat jet aased here crabed in Cuminck Sound, N.C. wbHle on a roudge taining masston Is two crewmien ejected sals ty. A probe bs onder way.

\section{WASHINGTON}

FICridata - The NRC por poser to flos the rishington Public Pawer Sunoly System \$75,00D ove the trat if nurs a reactor sate cy sy tem. The NRC folund three io. srances in 91 and 92 in whloh re-

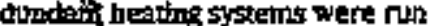
in violintipn of its rules

WESTVIAGINIA

CHAFiLsTON - Eght UM corkacs flanged in the strikerte lated Julfit2s slaying of nonminion worker Eld de York, 39, pleaded innocent te vial beglos Jan 24 the facil stit

\section{WISCONSIN}

NEIUSVILLE - A Oark COUR. 4 colse rehased to dismbs tratic doket given to ejght Antish men for drlving horsedrawn buggies

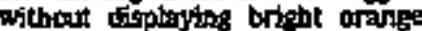
whow-moving tehide" siens. The mep sald fording the sigas on then volated their setigon.

\section{WYOMING}

JACXSON - Aoother wolf stehilag hes bees reported is the gavilen Valley of Yedrowstoge Ne 


\section{Joining forces \\ THE STATE

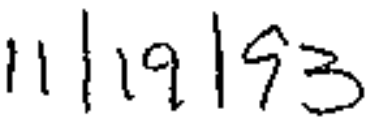 State universities create 'supercomputer network'}

BY ROBNAN

(I) mille

For yeqrz, South 'Carolina's research unfverslues have longed to join the high-tech world of superonta puters.

But stale gavernment's flnancla woes and perochlal blekering over where the equipment should be placed made acquisition a political hal potato.

Until now.

On Thursdny, the Universlty of South Carolling, Clepreon Universti and the Medical University of Soulh Carotina In Charleston formally jolned torces to creale a "superconaputer astwork" that should pot the stale in tast conpany when lt cencles to compulor-assisted research.

Gov, Carroll Camphell saw.a dernonsiration of the \$1.75 mitllab supercomputer at USC's momputer strvices burlding.

Al a hìgher education conference In November 1991, Campbell sald obLalning a supercomputer shoubd be a prlority. His iuterest is crediled by some as belng a calalyst for getila the universitites to put aside thelr diterances aboul ownership and contro].

Bobby Rowers, direclor of the stale reserarch and stailotlcal services dIvlston, sald, "I appland the Insktu. tions for caklag the lnlllallve in puti. Ing thls together. I think we're all coing to be winnars gs a resull.

In 19a9, USC and Clemson battled it out in, the Legislature with compet. ing requests for fubing so each coutd buy a supercomptles. The prlce las for one mackatre lopped $\$ 10$ million. Lawmakers strusgling to balance the bodged decided the stale couldat aflord two computers and named a insk torce to find a solntion.
That panel declded South Cacalln could use a supercomputer but wh unable to resolve where tit shomld be located, or who would be responstbl Ior lts operation and spalntentince.

flowers' gatid the governor's decislon to appolnt a second task forte nudged the undversilites into workto together.

By delayting the puchase, usc struck a deal with Intet Corp. to ac. qulce ils newest gopercompuler more than a year ago tor kess than 22 million. USC also agreed lo accept krants from the eompany and federai governdient, a move that cut the unlver. sity's cost to about $\$ 300,000$.

The machine was acquired through a research assoclation willh the U.S. Department of Energy, bul as agreosent will make at least half of the machine's compuline capacity avatlabla to resoarchers af USC,
Clemsion and MUSC.

Those who will be using the equip ment are excited abaut what it motan to South Carolina.

Jay Gogue, Clemson's top re search offledal, said the supercornputer wll help universițes recrult top profeseors.

Davld Hoel, chalrman of the blom. otry and epidemiology department at MUSc, called it "an Important col that can be useiul for a lot research"

A supercanputer, for example. can holp joedical researchers create modets of molecules they believe will enable them to Jdentijy new kinds of medicatlons to cure diseases.

Fred Carter, the Stale Budget and Conlrol Board director, sald "having Soulh Carolina as a technology bub Identities us . an extra-progressive state, If cerialnly makes us a more Inviting plree to tocale" - 
Gy efont unati counuerk "sc ofreals ur

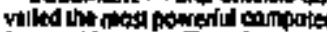

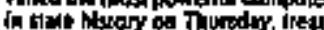

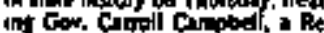

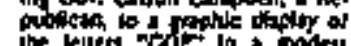

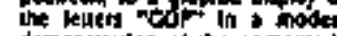
demolsutation of the compuker'z

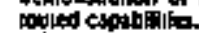

Howed at thit Uairetaly ol

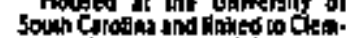

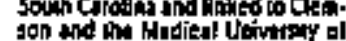
son and on Mudien! Uouttany al

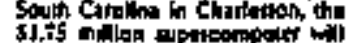

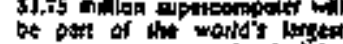

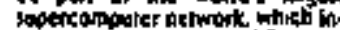

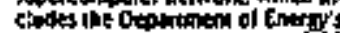

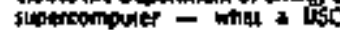

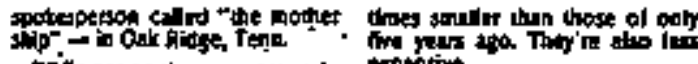

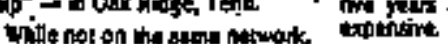

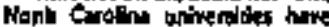

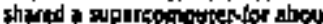
$10 \mathrm{max}$

"Ny alod earit carnpteturnt"

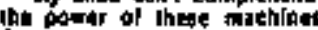
Caipbet aid.

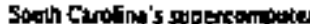

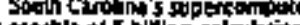

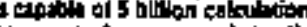
ofr wectint. epanpored to the Tez is blligh,

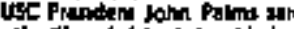
tinaty. II with I had lati kind of

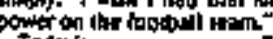

Tody's papaconaluere camp

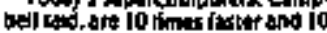

The Dopartment of Entory and

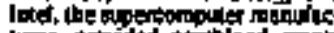

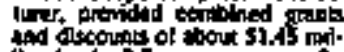

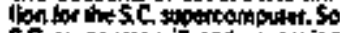

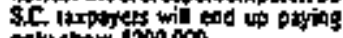
onty ano 500000 .

On 1909 ned 2950) we Fite

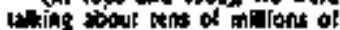
tellar per compules." unta tym lones. In mibles of the newds.

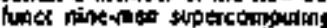

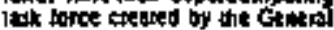
aspentoly

Dweng that tome the bagk loves noconirgatided the

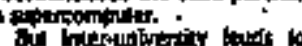

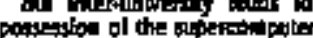

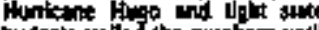
bodgety salied ins puaction un:!! ont

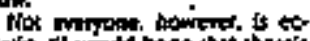

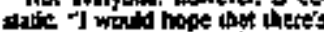

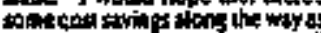

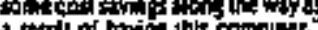

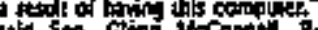
chation sen, who led the tight

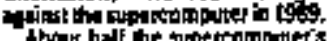
Abour hal the tupercompetests waber consa phatiog ax the bepan.

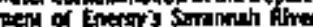

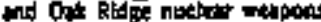

conglener The poter hall will be

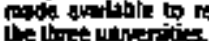

iny jeltover time miglat be letsed to omale tetsetothirs

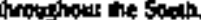
Nhear Gamben halled the

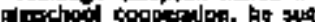

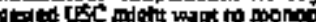
cine ant

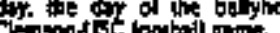

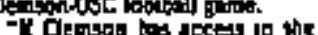
in che

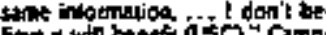

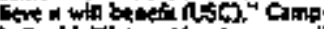

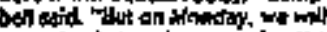
cores beck togeter io solve Ipe protina Jox Sowt Cacolina and

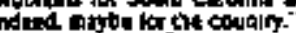




\section{across state}

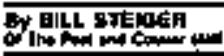

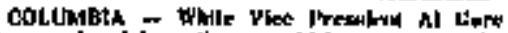

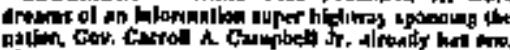
of 100 is

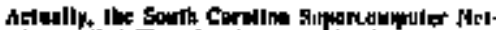

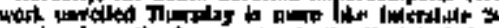

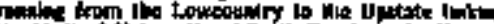

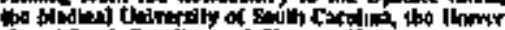

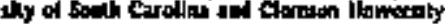

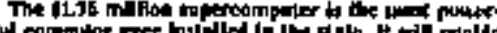

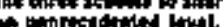

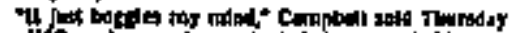

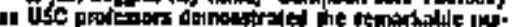

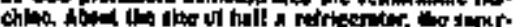

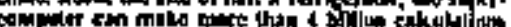
at

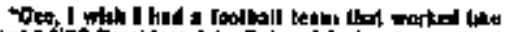

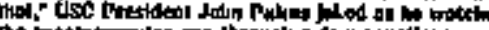

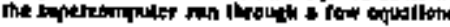

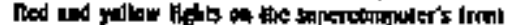

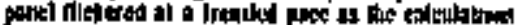

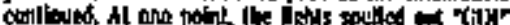

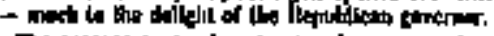

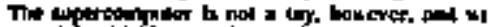

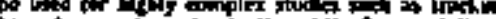

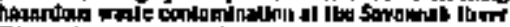

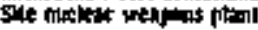

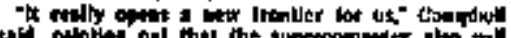

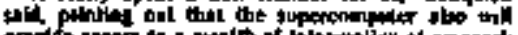

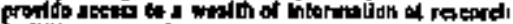

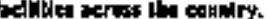

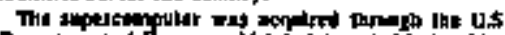

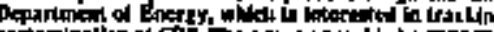

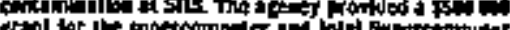

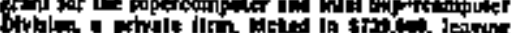

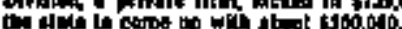

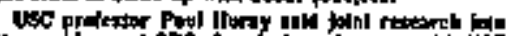

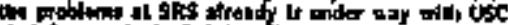

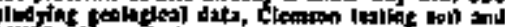

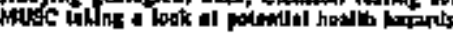

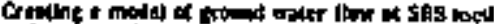

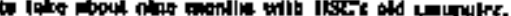

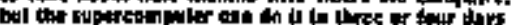

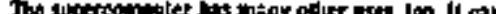

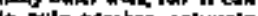
wind an tor

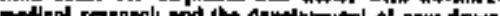

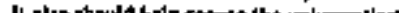

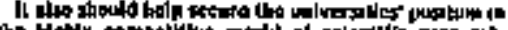

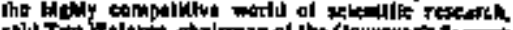

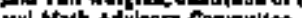

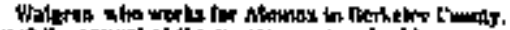

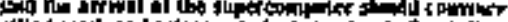

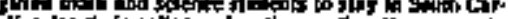

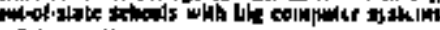

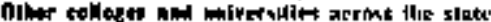

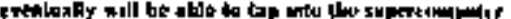

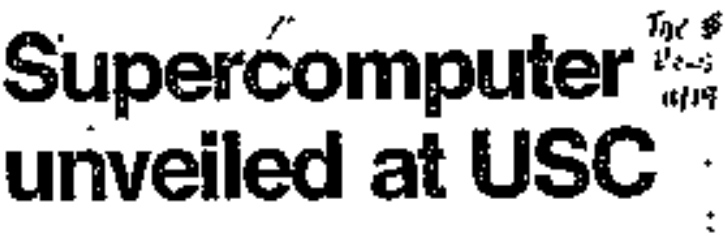

By Stanes T+ Hownond Nim Capied Buram

COLUMbla - Imngine bol

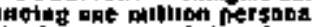

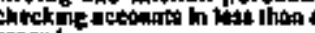
seconil

Tlars sule ofoed ol whlch a naw

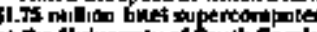
* ne Uidraraly of Sowaln Cardr

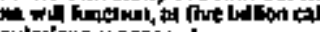
atbilons per sectrol

-I wabl I freol that hlad of gower

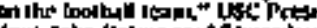

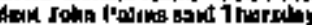

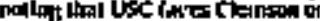

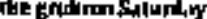

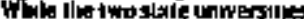
may loo hullund twols, thir re

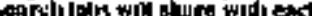
ouher atwl till lbe Mevical Uh

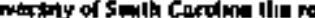

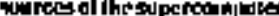

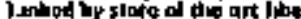

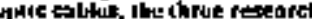

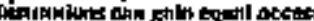

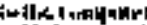

If lley need mode centopritin

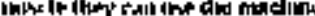

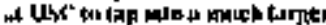

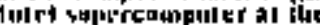

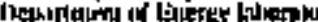

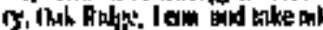

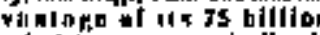

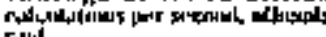

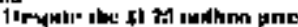

Lot soulh Corolkan god aod. he

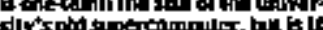

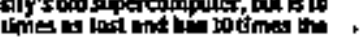
mailoory.

Souh Caroling wil spend tess

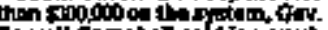

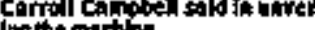
ig phe parr.

The 18,S. Deparimeat of En :

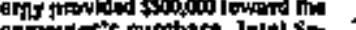
compulets purentst. InIe 35

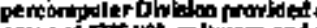

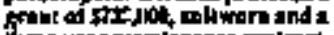

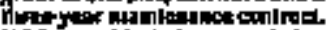
usc provided ate reminingr: $\sin , 000$

Poul Iruray, the principal ra Sestch idrestivalor boc tise Ep. ify Dupatintend gratur sad hit

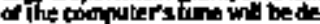

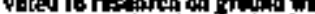
ler conlonminatina and other ormberilent proticint

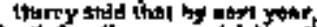
south Cordhe reaserdilabs wil

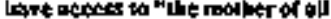

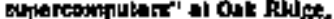

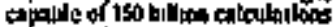
per $5=000$.

The Everith Deportmen! : vualing ale project at part of lito

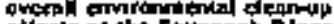
ctioris at the Strounab River sine, ofliliteltand. 